\title{
Reviewing Guidelines on Facilities and Practices of Intergenerational Care in Australia and Malaysia
}

\author{
Intan Liana Samsudin', Syed Iskandar Ariffin ${ }^{2}$, Maimunah Sapri ${ }^{3}$, Jamilia Mohd Marsin 1 \\ ${ }^{1} \mathrm{PhD}$ Candidate, Architecture, ${ }^{3}$ Real Estate, \\ Faculty of Built Environment \& Surveying, \\ 2 Institute Sultan Iskandar, \\ Universiti Teknologi Malaysia, Johor, Malaysia,
}

intanlianasamsudin@gmail.com, b-sahmad@utm.my, maimunahsapri@utm.my, jamilia2@graduate.utm.my Tel: +6017-8731277

\begin{abstract}
Developed countries like Australia have guidelines to support intergenerational care development for aged citizen. In Malaysia, the current facilities for aged care are single-user facilities and lack intergenerational interaction conducted with the other generations. The study reviewed the care facilities guidelines to support intergenerational interaction in the Malaysian context based on the Australian intergenerational care practice perspective. The qualitative method is employed through a comparative and content analysis of the guidelines. The finding showed that the childcare visitation model had been identified as a promising alternative intergenerational care to enhance intergenerational interaction in the Malaysian context.
\end{abstract}

Keywords: Intergenerational care facilities; Aged Care; Childcare; Guidelines

eISSN: 2398-4287@ 2021. The Authors. Published for AMER ABRA cE-Bs by e-International Publishing House, Ltd., UK. This is an open access article under the CC BYNC-ND license (http://creativecommons.org/licenses/by-nc-nd/4.0). Peer-review under responsibility of AMER (Association of Malaysian Environment-Behaviour Researchers), ABRA (Association of Behavioural Researchers on Asians/Africans/Arabians) and CE-Bs (Centre for Environment-Behaviour Studies), Faculty of Architecture, Planning \& Surveying, Universiti Teknologi MARA, Malaysia.

DOI: https://doi.org/10.21834/ebpj.v6i16.2720

\subsection{Introduction}

Rapid development in Malaysia and the changes impacting its built environment, contribute to social change and living condition. The development brings forth greater good by improving standard of living and restore the quality of life. However, the development also affects adults' lives with their elderly parents as they care for them. The most significant impact is the challenges in striking a balance between the care process of the elderly and meeting up with usually demanding career responsibility (N. Hudani et al., 2016). Some elderly are sent to live in nursing homes due to a lack of informal and professional care (Luppa et al., 2010). Despite the advantages of living at the nursing home, aspect such as the quality of life, especially the activities and social satisfaction domains, are lacking (Maenhout et al., 2019). One probable solution in meeting the social satisfaction demands by introducing intergenerational programs (Newman \& Hatton-Yeo, 2008; Maccallum et al., 2010) and intergenerational care (IC) perspectives (Hayes C.L, 2003; Jarrott et al., 2006). The IC can benefit aged people and has proved to benefit children development. Newman et al. (1997) stated that with a growing number of children raised in single-parent homes and households where both parents are working, the number of children receiving nonparental care had increased significantly in the past decade. It is estimated that Malaysia should have about 38,000 childcare facilities, but surprisingly it has only 4,300 (Azaman, 2018). The forecast showed that the demand for childcare facilities is increasing, and the number of populations over 60 years old in Malaysia is also rising. In brief, the aged and children need more interaction for the

eISSN: 2398-4287@ 2021. The Authors. Published for AMER ABRA cE-Bs by e-International Publishing House, Ltd., UK. This is an open access article under the CC BYNC-ND license (http://creativecommons.org/licenses/by-nc-nd/4.0). Peer-review under responsibility of AMER (Association of Malaysian Environment-Behaviour Researchers), ABRA (Association of Behavioural Researchers on Asians/Africans/Arabians) and cE-Bs (Centre for Environment-Behaviour Studies), Faculty of Architecture, Planning \& Surveying, Universiti Teknologi MARA, Malaysia.

DOI: https://doi.org/10.21834/ebpj.v6i16.2720 
social and emotional well-being as support for the biological ageing process nor biological development process. What are the current guidelines of care facilities sector, and how the intergenerational program and care have been practiced in the Malaysian context? Hence, the study aimed to review the care facilities guidelines needed to support intergenerational interaction in the Malaysian context based on the Australian IC practice perspective. Objectives of research are to identify the existing local implementation of the intergenerational practice, identify the Australian approach and practices on IC facility, and compare the physical environment elements in the guidelines with the intent to form a way forward practice and implementation.

\subsection{Overview of Intergenerational Practice and Intergenerational Care}

Intergenerational practices are any activities that bring people together in purposeful, mutually beneficial activities that promote greater understanding, respect between generations and contribute to building more cohesive communities (Finn C \& Scharf T., 2012). Intergenerational care refers to care models that bring together older people and children in a shared setting for their mutual benefit through activities aim to meet specific life goals (Wadworth \& Whitehouse, 2007). The original rationale behind the intergenerational programme was that older adults possessed the knowledge to pass down to their grandchildren, creating a process in which both grandparents and grandchildren benefited (Newman et al., 1997). However, in modern, more complex societies, intergenerational learning is no longer transmitted by the family alone and increasingly occurs outside the family (Newman \& Hotton Yeo, 2008). As for today's, the IC has developed in a few contexts of care facility including the exchange happen between the aged care facility with the preschool students through intergenerational program exchange (Kocarnik \& Ponzdetti Jr, 1991; Newman \& Ward, 1992), nursing home care intergenerational exchange with the community (Wu et al., 1997) and some research also covers dementia elderly intergenerational program with children (Newman \& Ward,1992). Generally, the IC program can take place in many forms, setting and target group. 4 key components needed to support the intergenerational practice are the targeted group, program objectives or purpose, intergenerational activities and setting (Ngu, 2016). Each country has its niche and choice of program to conduct the intergenerational practice. The IC has been implemented in a developed country such as the United States, United Kingdom, Europe and Asia, including Singapore, to develop an inclusive society and community. However, this research focuses on the intergenerational practice in Australian context due to recent contributions related to IC perspective (Radford et al., 2016; Vecchio et al., 2017; Radford et al., 2018) with care facilities in Malaysian context.

\subsection{Malaysian Intergenerational Practice}

In Malaysia, the intergenerational program has started in 1996 (Tan \& Tey, 2005), conducted in a community centre through a community-based module. Although the intergenerational program's implementation has been established for more than two decades, this program's implantation is actively carried out in recent years. This approach is to align towards the vision of National Aged Policy. The intergenerational programme consists of several modules. The common modules focus on community and aged care compared to a shared site module.

- Community-based module:

One of the documented community programs is at the Petaling Jaya Community Centre between the elderly and children (Tan \& Tey, 2005). The recent intergenerational program implemented is based on the state government initiatives such as Johore, Perlis, Selangor, Kedah and Terengganu. Most of the program conducted within the community neighbourhood and the volunteers mostly involve teenagers or students from colleges and universities.

- $\quad$ Aged care module:

Some intergenerational program is conducted at the aged care centre area. In 2019, the intergenerational program conducted at Older People Activity Centre, Sebuyau, Sarawak, as one of the initiatives by the state government and Social Welfare Department. Additional IC implementation is the activity conducted by 20 University students at the Sri Permai Aged Care, which involves the spring cleaning, cooking, and assisted activity by Mara Polytechnique College, Kuantan, as part of corporate social responsibility initiative.

- $\quad$ Shared site module:

The shared site IC program is not a common care module. One of the evidence of the shared site module is Titian Kasih House as one of the care initiatives under the Social Welfare Department, which is occupied by elderlies, single mothers, and children.

The intergenerational program's common model is a single site program, where the program is conducted at a religious centre, community centre, university campus and training centre location. Additionally, some community-driven program has been conducted at the school field, a nearby community hall, and shopping malls (Tan \& Tey 2005). Generally, the strong emphasis on communitybased is seen as 20 programs implemented in 2018 nationwide involving a number of 3,710 participants with a population of 1,667 elderlies, 1,035 children and 1,008 teenagers related to the intergenerational program. They consist of elderlies from different group such as volunteers, institutions, Older People Activity Center and the community itself. Younger participant consists of students from university, school, and children from Children Activity Centre (A. Shukri \& A. Hamid, 2018).

\subsection{Australia Intergenerational Practice}

Over the past decade in Australia, initiatives designed to support young people's engagement and civic involvement have grown in popularity, especially in policy literature and communitarian aspirations such as building community, promoting civics, and encouraging social capital (Maccallum et al., 2010). In Australia, the five modules of the intergenerational program are based on the following: 
- Mentoring based module:

Royal South Street Society in Ballarat is a module where older volunteers increase their coaching and mentoring skills as they facilitate youth's learner regarding artistic and social abilities. Older volunteers facilitate youths' learning by providing encouragement, reinforcing the competitors' artistic skills, and learning social skills. Competitors and volunteers learn together that intrinsic rewards outweigh extrinsic values. (Newman \& Hatton Yeo, 2008).

- Community-based module:

An example of this module is the community-based arts organisation Big hART and performance tour "Ten Days on the island" art festival in 1960 and 1970. Secondly, the Yiriman Project, West Kniderley, for young people, particularly those who were harming themselves with drugs, alcohol and getting in trouble with the law. Following long-established traditions, they set up an organisation that would help bring young people, elderlies, and community members to a trip around the country (Maccallum et al., 2010).

- Aged care-based module:

The Bankstown Oral History project is where high school students' pairs with the local aged club and ethnic respite centre to written up the personal life stories and published by BYDS in 1990-2002 (Maccallum et al., 2010).

- Childcare based module:

Intergenerational program between nursing home residents and preschoolers is evidence for childcare-based modules by applying collocated preschool engagement (Low et al., 2015).

- School-based module:

School volunteer programs between school-age young people from kindergarten to year 12 and volunteer mentors are mainly the elderlies. Training is provided for volunteer mentors in listening skills, helping children read, drug awareness, bullying and suicide prevention (Maccallum et al., 2010).

Concerning the IC program, the Australian context has implemented the aged care based and childcare based module. Vecchio et al. (2017) highlighted three possibilities for intergenerational programs in Australia: centre-based visitation, shared campus care, and single home care. The scope centre-based visitation model refers to the childcare and aged care services delivered independently on separate sites while IC activities conducted at a designated time on a designated day, with one generation being transported to another's principal place of care. The shared campus refers to the childcare and aged care services delivered on a single site, including a shared space/common area for supervised intergenerational activities. Intergenerational activities are to be optional and supervised by appropriately trained staff. In contrast, the family daycare is single-home care that provides a similar set of economic advantages, drawing upon existing infrastructure in the Australian family daycare environment. The family daycare model of IC could provide childcare and aged care services delivered on a single site in a residential home situated within the community.

\subsection{Document Review of Care Guidelines}

Several major reporting on the aged care, childcare and IC guidelines are compiled to conduct document review data collection. Malaysia's selected guidelines are referred to aged care and childcare facilities, while it is based on IC guidelines in Australia. The influence factor for document review selection is based on the need to gathered information on IC environment from the childcare and aged care perspective. In the context of this research, the physical environment for the aged care and childcare facilities were compared to the IC facilities to identify the design indicator criteria's and way forward of a possible implementation of IC program, module and model in Malaysia. The selection of guidelines is gathered using the snowball technique via searching through google scholar, planning websites and related government agencies in each country. The selected guidelines in the Australian context is based on the Griffin University IC report. Guidelines for the Malaysian context is based on the Ministry of Women, Family and Community Development, and the Ministry of Housing and Local Government. The guidelines main characteristics are in Table 1. For the data analysis, content analysis is used to analyse text (Powers \& Knapp, 2006) of the guidelines. The process involved in the content analysis is preparation, organisation and reporting (Elo \& Kyngas, 2008) for both guidelines. After the design indicators are coded, the theme/categories pattern is constructed based on the physical environment's descriptive phenomenon in both contexts.

Table 1. Key characteristics of guidelines in care scopes

\begin{tabular}{|c|c|c|c|c|c|c|c|}
\hline Country/Criteria & Australia & & Malaysia & & & & \\
\hline $\begin{array}{l}\text { Cluster of } \\
\text { guidelines }\end{array}$ & Intergenerationa & sare & Aged care & & & Childcare & \\
\hline Guidelines & $\begin{array}{l}\text { Intergenerational } \\
\text { Learning } \\
\text { Program } \\
\text { Operational } \\
\text { Guidelines and } \\
\text { Toolkit }\end{array}$ & $\begin{array}{l}\text { The } \\
\text { intergenerational } \\
\text { care project } \\
2019\end{array}$ & $\begin{array}{l}\text { Community } \\
\text { Facilities } \\
\text { Planning } \\
\text { (Revision 1997) }\end{array}$ & $\begin{array}{l}\text { Senior Citizen } \\
\text { Physical } \\
\text { Planning }\end{array}$ & $\begin{array}{l}\text { Senior Citizen } \\
\text { Activity } \\
\text { Guidelines } \\
\text { (Revision 2018) }\end{array}$ & $\begin{array}{l}\text { Community } \\
\text { Facilities } \\
\text { Planning } \\
\text { (Revision 1997) }\end{array}$ & $\begin{array}{l}\text { Kindergarten } \\
\text { and Nursery } \\
\text { Guidelines }\end{array}$ \\
\hline
\end{tabular}




\begin{tabular}{|c|c|c|c|c|c|c|c|}
\hline Developer & Griffith University & Griffin University & $\begin{array}{l}\text { Plan Malaysia } \\
\text { (Urban and } \\
\text { Rural Planning } \\
\text { Department) }\end{array}$ & $\begin{array}{l}\text { Plan Malaysia } \\
\text { (Urban and } \\
\text { Rural Planning } \\
\text { Department) }\end{array}$ & $\begin{array}{l}\text { Social Welfare } \\
\text { Department }\end{array}$ & $\begin{array}{l}\text { Plan Malaysia } \\
\text { (Urban and } \\
\text { Rural Planning } \\
\text { Department) }\end{array}$ & $\begin{array}{l}\text { Plan Malaysia } \\
\text { (Urban and } \\
\text { Rural Planning } \\
\text { Department) }\end{array}$ \\
\hline $\begin{array}{l}\text { Date of } \\
\text { publication }\end{array}$ & 2019 & 2019 & 2013 & 2018 & 2018 & 2013 & 2017 \\
\hline User & $\begin{array}{l}\text { Intergenerational } \\
\text { (Older People } \\
\text { and Children) }\end{array}$ & $\begin{array}{l}\text { Intergenerational } \\
\text { (Older People } \\
\text { and Children) }\end{array}$ & Community & Older People & Older People & Community & Children \\
\hline Interpretation & $\begin{array}{l}\text { Development, } \\
\text { implementation, } \\
\text { and evaluation of } \\
\text { Intergenerational } \\
\text { Learning } \\
\text { program }\end{array}$ & $\begin{array}{l}\text { Evaluating } \\
\text { Intergenerational } \\
\text { learning program }\end{array}$ & $\begin{array}{l}\text { Healthcare, } \\
\text { educational, } \\
\text { Safety and } \\
\text { Rescue, } \\
\text { Community, } \\
\text { Library and } \\
\text { Welfare }\end{array}$ & $\begin{array}{l}\text { Planning } \\
\text { Principle, Aged } \\
\text { care centre, } \\
\text { Residential, } \\
\text { Design } \\
\text { guidelines, and } \\
\text { Strategic Plan }\end{array}$ & $\begin{array}{l}\text { Organisation, } \\
\text { Establishment, } \\
\text { Supervision, } \\
\text { Operational, } \\
\text { Activities, } \\
\text { Management } \\
\text { and Safety. }\end{array}$ & $\begin{array}{l}\text { Healthcare, } \\
\text { educational, } \\
\text { Safety and } \\
\text { Rescue, } \\
\text { Community, } \\
\text { Library and } \\
\text { Welfare. }\end{array}$ & $\begin{array}{l}\text { Planning } \\
\text { Principal, } \\
\text { Development } \\
\text { guideline, } \\
\text { Establishment } \\
\text { and Building } \\
\text { Safety }\end{array}$ \\
\hline
\end{tabular}

\subsection{Result}

Analysis from Australia and Malaysia guidelines has formulated 21 design indicator codes as per Table 2. Based on the codes, 4 sets of categories are constructed. The developed themes are local and neighbourhood; built form; space component; space simulation, and experience concerning care setting parameter. IC guidelines' content analysis consists of 14 design indicators out of 21 indicators related to the physical environment. The intergenerational design indicators' scope is developed based on the shared site and visitation models at the childcare centre or aged care centre. The developed indicators based on IC scope focus on the elderly and children from 3 to 5 years old. The guidelines emphasise the site character and environment as important strategies for IC program implementation stage. The major assessment and selection criteria for IC programmes are based on the built form, space simulation and experience categories. The general assessment of the built form for IC facility includes accessibility, user-friendly environment, safety, security, barrier-free and physical infrastructure such as parking area and drop off proximity to the entrance. The space stimulation and experience category indicate interactive, and flexibility indicators are significant, followed by the materiality, wayfinding and supporting facilities. In a macro context, the accessibility to public transportation is significant for logistic and travelling purposes to conduct IC program.

In Malaysian context, the design indicators develop from the Community Facilities Planning Guidelines is specifically for Older People Activity Centre facility, while the design indicator for Senior Citizen Physical Environment Guidelines focuses on the general aged care facilities perspective. The design indicators' trend develops for the aged facilities emphasising the built form and the space component. The space component covers the type of spaces required for the aged care facility, such as recreational area, religious space, management space and healthcare space. In addition, it shows the recreational area, healthcare area, and religious area essential for the elderly, especially in the local context. Although 17 design indicators are documented about the aged care facilities' physical environment, there is a lack of design indicators describing space values and experience, especially for social interaction needs. Meanwhile, the indicators for childcare facilities guidelines constructed based on the Childcare Activity Centre, Kindergarten and Nursery facilities. 16 design indicators are found based on 2 guidelines. The development of childcare centre focuses on the built form, local and neighbourhood context. In practice, the consideration of childcare development placement is mainly located in the area where young families mostly reside. Furthermore, an integrated building facilities indicator is important where schools, community centre or clinic are integrated within the neighbourhood. Although the guidelines in Malaysia context emphasise the singular user facilities, some guideline has consideration and provision for the intergenerational facility. These include the need for interaction space between the elderly and children generation, community-based development planning for all, vertical facilities requirement in high-density community facilities, universal design consideration and recreational space requirement as part of the design criteria.

In a nutshell, most of the care facilities guidelines focus on the built form design criteria. However, in the scope of space experience and simulation, the existing aged care and childcare facilities guidelines does not specify a details design indicator to support the IC program. The existing childcare centre and aged care centre's evaluation is deemed necessary to support the care centre's social interaction to successfully implement the IC program, especially for visitation care model. The flexibility, interactive and supporting facilities design indicator must be considered upon the IC program's planning stage. Table 3 indicates the matrix of intergenerational care facilities summary. In Australia, the established care model is a visitation model and shared site model. In Malaysia, the visitation model is acceptable and feasible at the aged care facilities setting, which commonly involves the tertiary students compared to the children's involvement. The implementation of visitation IC model in Australia context conducted at the respite care centre, while in Malaysia, it is implemented at the Aged Care Centre and Older People Activity Centre.

Table 2. Intergenerational Care Facilities Design Indicators

\begin{tabular}{|c|c|c|c|}
\hline $\begin{array}{c}\text { Local and } \\
\text { Neighbourhood }\end{array}$ & Built Form & Space Component & Space Stimulation and Experience \\
\hline
\end{tabular}




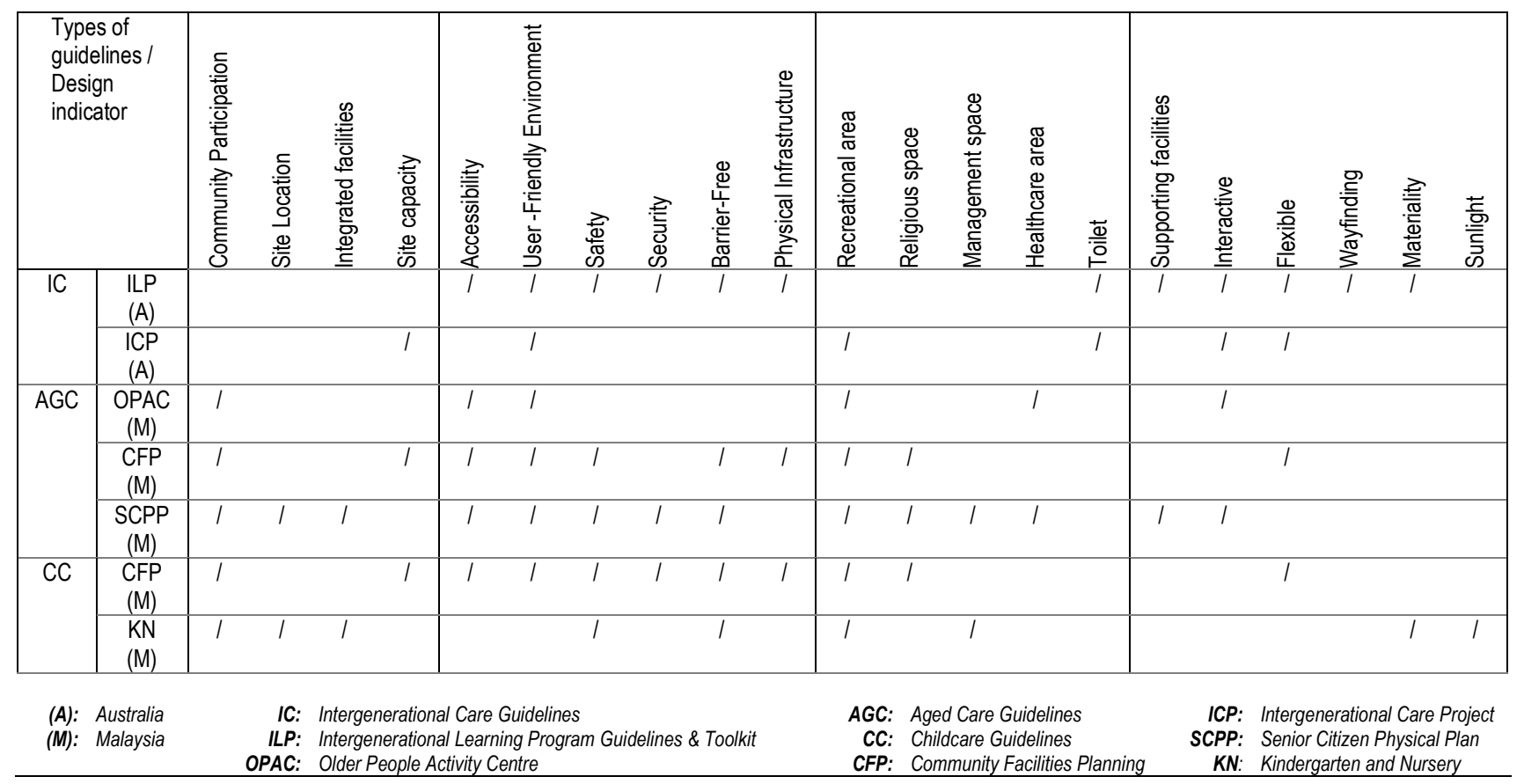

Table 3. Intergenerational Care Facilities and Model

\begin{tabular}{|c|c|c|c|c|c|c|}
\hline $\begin{array}{l}\text { Scope of } \\
\text { intergenerational } \\
\text { module }\end{array}$ & $\begin{array}{l}\text { Types of care } \\
\text { module }\end{array}$ & $\begin{array}{l}\text { Practices of } \\
\text { intergenerational } \\
\text { care model }\end{array}$ & Malaysia & Setting & Australia & Setting \\
\hline \multirow[t]{3}{*}{$\begin{array}{l}\text { Care centre based } \\
\text { module }\end{array}$} & $\begin{array}{l}\text { Shared site } \\
\text { intergenerational } \\
\text { module }\end{array}$ & $\begin{array}{l}\text { Shared site model/ } \\
\text { Co-location (shared } \\
\text { space) }\end{array}$ & 1 & Integrated care & I & $\begin{array}{l}\text { Community hall } \\
\text { Common Room }\end{array}$ \\
\hline & $\begin{array}{l}\text { Aged care centre } \\
\text { based module }\end{array}$ & Visitation & 1 & $\begin{array}{l}\text { Older People } \\
\text { Activity Centre \& } \\
\text { Aged care }\end{array}$ & 1 & Respite care \\
\hline & $\begin{array}{l}\text { Children centre } \\
\text { based } \\
\text { intergenerational } \\
\text { module }\end{array}$ & Visitation & - & - & 1 & Child daycare \\
\hline
\end{tabular}

\subsection{Discussion}

Intergenerational practice and care are not a new direction in the Malaysian context. The visitation model at the childcare and Children Activity Centre may be the path of IC practice. The strong emphasis on the Older People Activity Centre potentially enhances the childcare industry's engagement for social, learning communication, empathy values and reduced the ageing stereotypes perception. The main issue for the elderly that stay at the nursing home is a lack of engagement with the community or family members (Nurhayati et al., 2017). Visitation from or to a childcare centre will improve emotional well-being, avoid loneliness, enhance their quality of life and foster a positive contact theory development through positive intergroup relationship. The local and neighbourhood level assessment could be the additional criteria to understand the IC program's context. Review existing built form and space experiences design indicators is deemed necessary for the IC program implementation. The research findings have also highlighted the need for a religious space component, especially for aged people. The accessibility, user friendly, safety, barrier-free, flexibility and interactive are necessary design indicators for intergenerational engagement with support from previous intergenerational environment research (Kaplan et al., 2007; Larkin et al., 2010). The outline design indicators can be used to guide the development of shared site facilities and assess the existing care facilities for a visitation model. However, the developed design indicators may require further research, especially in childcare or aged care settings, to be modified as a shared site facility.

\subsection{Conclusion \& Recommendations}

In conclusion, both visitation module is dual-able either the care program is at the childcare or aged care setting. It is important to carry out the care centre character's assessment to decide which space offered a better environment and a well-equipped IC program. For the program implementation, the program procedures, logistic, participants scale, activities, facilitators' relation, and space environment need to be considered holistically to ensure that the program is a success based on the lesson learned from the Australia IC guidelines. 
To creating an enjoyable experience of IC activities, choosing an appropriate environment to facilitate the best intergenerational interaction is needed.

\section{Acknowledgement}

Thank you to the Ministry of Higher Education (MOHE) for the financial supports through Fundamental Research Grant Scheme grant (FRGS No: FRGS/1/2019/SSI11/UTM/01/1, Vot No. 5F148) and Universiti Teknologi Malaysia for the support.

\section{Paper Contribution to Related Field of Study}

This paper contributes to the field of Inclusive Design and Built Environment research.

\section{References}

A. Shukri A. Hamid \& Norliza M. (2019), Agenda dan Keberhasilan Program Intergenerasi Warga Emas, Kanak-Kanak Dan Remaja Jabatan Kebajikan Masyarakat, MASW-JKM-ISM International Social Work Symposium. Institut Social Malaysia, Kuala Lumpur.

Azaman (2018, September 18). Malaysia kekurangan pusat jagaan kanak-kanak - TPM. Astroawani.Com. https://www.astroawani.com/berita-malaysia/malaysiakekurangan-pusat-jagaan-kanak-kanak-tpm-185892,

Elo, S., \& Kyngäs, H. (2008). The qualitative content analysis process. Journal of Advanced Nursing, 62(1), 107-115

Finn C. \& Schart T. (2012). Intergenerational Programmes in Ireland: An Initial Overview. Dublin: Irish Centre for Social Gerontology, National University of Ireland Galway. Hayes, C. L. (2003). An Observational Study in Developing an Intergenerational Shared Site Program. Journal of Intergenerational Relationships, 1(1), 113-132.

Jarrott, S. E., Gigliotti, C. M., \& Smock, S. A. (2006). Where Do We Stand? Testing the Foundation of a Shared Site Intergenerational Program. Journal of Intergenerational Relationships, 4(2), 73-92.

Kaplan, M., Haider, J., Cohen, U., \& Turner, D. (2007). Environmental Design Perspectives on Intergenerational Programs and Practices. Journal of Intergenerational Relationships, 5(2), 81-110.

Kocarnik, R. A., \& Ponzetti, J. J. (1991). The Advantages and Challenges of Intergenerational Programs in Long Term Care Facilities. Journal of Gerontological Social Work, 16(1-2), 97-107.

Larkin, E., Kaplan, M. S., \& Rushton, S. (2010). Designing Brain Healthy Environments for Intergenerational Programs. Journal of Intergenerational Relationships, 8(2), 161-176.

Low, L.-F., Russell, F., McDonald, T., \& Kauffman, A. (2015). Grandfriends, an Intergenerational Program for Nursing-Home Residents and Preschoolers: A Randomised Trial. Journal of Intergenerational Relationships, 13(3), 227-240.

Luppa, M., Luck, T., Weyerer, S., Konig, H.-H., Brahler, E., \& Riedel-Heller, S. G. (2010). Prediction of institutionalisation in the elderly. A systematic review. Age and Ageing, 39(1), 31-38

MacCallum, J., Palmer, D., Wright, P., Cumming-Potvin, W., Brooker, M., \& Tero, C. (2010). Australian Perspectives: Community Building Through Intergenerational Exchange Programs. Journal of Intergenerational Relationships, 8(2), 113-127.

Maenhout, A., Cornelis, E., Van de Velde, D., Desmet, V., Gorus, E., Van Malderen, L., Vanbosseghem, R., \& De Vriendt, P. (2019). The relationship between quality of life in a nursing home and personal, organisational, activity-related factors and social satisfaction: a cross-sectional study with multiple linear regression analyses. Aging \& Mental Health, 24(4), 649-658

N. Hudani Nawi, P. Hayati Megat Ahmad, M. Dahlan A. Malek, G. Cosmas, Habibie Ibrahim, Peter Voo and Winda Kiyah (2016), Intergenerasi, Sokongan Psikologi dan Sosial Penjagaan Warga Tua dalam Pelbagai Etnik di Sabah, Southeast Asia Psychology Journal, 4(1), 24-34

Newman, S., \& Ward, C. (1992). An Observational Study of Intergenerational Activities and Behavior Change in Dementing Elders at Adult Day Care Centers. The International Journal of Aging and Human Development, 36(4), 321-333.

Newman. S., Ward, C.R., Smith, T.B., Wilson, J.O., and McCrea, J.M. (1997) Intergenerational Programs: Past, Present and Future. Washington: Taylor and Francis, 55-79.

Newman S., Hatton-Yeo A. (2008). Intergenerational Learning and the Contributions of Older People. Ageing Horizons, 8(1), 31-39.

Ngu K. Shing (2016). Pembangunan Modul Kurikulum Intergenerasi Berasaskan Perkongsian Kemahiran (Doctoral dissertation, Universiti Malaya, Malaysia)

Nurhayati M, Khadijah Alavi, M. Suhaimi M, N. Saadah M. Aun (2017), Pengalaman Sokongan Sosial Intergenerasi dalam Kalangan Warga Emas di Institusi Kebajikan Awam, Akademika 87 (1): 65-74

Powers B, Knapp T (2006). Dictionary of Nursing Theory and Research (3rd edn). New York: Springer Publishing Company, 
Radford, K., Gould, R., Vecchio, N., \& Fitzgerald, A. (2018). Unpacking intergenerational (IG) programs for policy implications: A systematic review of the literature Journal of Intergenerational Relationships, 16(3), 302-329.

Radford, K., Oxlade, D., Fitzgerald, A., \& Vecchio, N. (2016). Making Intergenerational Care a Possibility in Australia: A Review of the Australian Legislation. Journal of Intergenerational Relationships, 14(2), 119-134.

Tan P. Chang \& Tey N. Peng (2005), PJCC-A Model for Community Participation and Active Ageing in Malaysia, Journal of Intergenerational Relationship, Vol.3(2), $125-131$

Vecchio, N., Radford, K., Fitzgerald, J. A., Comans, T., Harris, P., \& Harris, N. (2017). Intergenerational care: an exploration of consumer preferences and willingness to pay for care. Aging \& Mental Health, 22(8), 996-1004.

Wadsworth, N. and P. Whitehouse (2007). "Intergenerational Care" In the Encyclopaedia of Elder Care, edited by M. Mezy. New York: Springer.

Wu S. C., Li C. Y., Chang A. (1997). The influence of intergenerational exchange on nursing home admission in Taiwan. Journal of Cross-Cultural Gerontology, 12(1) 163-174. 